\title{
NON-DISCLOSURE OF EVIDENCE, ADVERSE INFERENCES AND THE COURT'S SEARCH FOR TRUTH
}

\author{
HENRY L. MOLOT*
}

\begin{abstract}
Professor Molot examines the interaction of two omnipresent and often conflicting premises of the trial process: the "truth theory" and the adversary system. In order to promote a pure adversarial struggle and thereby allow either side to present its strongest case, it would appear necessary to ac. cord counsel ultimate discretion as to whether known evidence should be disclosed at trial or concealed. The author observes, however, that such unlimited discretion has been modified by the courts and the legislatures in order to insure the presentation of a complete and truthful evidential picture. As a result of this necessary modification certain adverse inferences of fact have been developed to aid the court in assessing the effect of non-disclosure on the evidence adduced by either adversary. Using the "truth theory" and the "adversary theory" as a foundation the author discusses the development of adverse inferences in the light of case law, both criminal and civil, in order to define and evaluate some of the underlying principles of the trial process.
\end{abstract}

In the trial process devised by the common law it is intriguing to observe how difficult a task the courts have set themselves in trying to produce harmonious accord between, on the one hand, their claims in favour of a search for the truth and, on the other, the rules they have from time to time promulgated to further these claims. It has been stated by Lord Denning that the object of the judge sitting as a trier of fact "above all, is to find out the truth, and to do justice according to law."1 However, the alleged pursuit of this ultimate goal has been nourished not only by multitudinous rules of evidence but by a system of trial based on "powerful statements on both sides of the question," 2 the adversary process. The foundations of the law of evidence establishing the material issues of facts by means of relevant evidential facts, would seem on the surface to provide a goodly measure of confidence in the achievement of this goal. This optimism is not necessarily beclouded by the presence of exclusionary rules against otherwise relevant evidence which experience has demonstrated too often leads the trier of fact astray. But this note of encouragement cannot be sustained in the face of rules that seem applied blindly over and over again without any re-assessment of the character of the modern jury, ${ }^{3}$ the fact that many of these rules were formulated in days when juries were far more prevalent, ${ }^{4}$ and the growth of modern technology. 5 But however much the vari-

* B.A. (Toronto), LL.B., LL.M. (Yale), of the Canadian Department of Justice. The views expressed in this article are the author's own, and do not necessarily represent those of the Department of Justice or Govern. ment of Canada.

1 Jone's v. National Coal Board [1957] 2 Q.B. 55 at 63 (C.A.). On the trial's search for the truth and some of the inherent limitations in this function, see Weinstein, Some Difficulties in Devising Rules for Determin ing Truth in Judicial Trials, (1966) 66 Col. 1. Rev. 223 at 229.241: Cleury, Evidence as a Problem in Communicating, (1952) 5 Vand L. Kev. 277n.

2 Ex p. Lloyd (1822) Mont. 70 at 72.

3 E.g., Koebel v. Rive [1958] O.R. 448 (C.A.); Hellenius v. Lees [1971] 1 O.R. 273 (C.A.) appeal to Supreme Court dismissed, Bulletin (27th April, 1971) 164. See Weinstein, supra, n. 1 at 255.

- E.g., Nokes, The English Jury and the Law of Evidence, (1956) 31 Tulane L. Rev. 153.

s Compare Myers v. D.P.P. [1965] A.C. 1001 with R. v. Rice [1963] 1 Q.B. 857 (C.A.) and Ares v. Venner (1970) 14 D.L.R. (3d) 4 (S.C.C.). Legislatures have moved to keep up with these developments: Canada Evidence Act, R.S.C. 1952 c. 307,8 . $29 \mathrm{~A}$, as amended by 17.18 Eliz. II, c. 14; Ontario Evidence

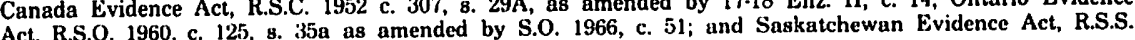
1965 , c. 80 , s. $30 \mathrm{~A}$ as amended by S.S. 1969 , c. 51 . 
ous rules of evidence assist in, or derogate from, the truth-seeking process, it is the other corner-stone of the modern trial, one which pits the forensic wits and qualities of one counsel against another, that has led many an acute, but skeptical, observer 6 to doubt whether this process plays the dominant role which the litany would give it.

For if the judge, subject to certain limited exceptions, must remain above the fray, and it is the advocates who are charged with the task of putting "the weights into the scales," that is, of adducing relevant evidence and examining witnesses in a manner which will tend to prove the propositions of fact each of them must establish to succeed, it would seem to follow that the judge is not so much making "up his mind where the truth lies"7 as he is deciding what evidence he will believe. It is here that the forensic and rhetorical powers of counsel can play so large a part in determining the outcome of a case. This conclusion is supported by the informal ranking of counsel by the profession itself and by a public willing to pay a higher fee for the better man, as well as in the many books written on the subject of advocacy by its more experienced and successful proponents. This "fight" theory, as Jerome Frank described it, has been purposefully modified in favour of the "truth" theory by such measures as expanded legal aid programmes, which if they cannot equalize the forensic powers possessed by the parties, ${ }^{8}$ will at least ensure that some modicum of legal representation is made available to greater numbers, and by rules of procedure that not only underline disclosure to the parties of the facts and law that are in issue but permit the parties, through the discovery process, to have access to many of the sources of these allegations of fact. In spite of the continued virility of such doctrines as competency, compellability and privilege in the law of evidence, all of which present illustrations of rules that probably exclude evidential facts of great relevance, there are modifications of an opposite order which both increase the range of admissibility ${ }^{9}$ and, equally vital, give the opposite party an even better opportunity than is to be found in the rules governing discovery to look at the litigant's case before trial. 10

It might well be argued here that a greater knowledge beforehand of an opponent's case will accentuate rather than weaken the "fight" theory. However, if we are to accept the present adversary system as one of the premises of the trial process, however modified it may be within the context of criminal law, then it will be desirable to encourage the most complete disclosure of relevant facts to one's opponent who then will be in a better position to test the strength of his own case against the one he must meet from the other side. Should he settle or should he do battle? If the latter course is to be pursued, how may he do so in the most telling and effective manner? For now

- E.8., J. Frank, Courts on Trial, (1949) chapter 6.

7 Jones v. National Coal Board, supra, n. 1 at 64. See also Phillips v. Ford Motor Co. of Canada Ltd. [1971] 2 O.R. 637 at 659 (C.A.), notice of appeal to Supreme Court filed. Bulletin (14th May, 1971) 185.

s It is interesting to note here the prevalence of a reasoning process that had so profound an effect on labour-management relations. A laissez-faire approach in the field of employment contracts could be retained by equalizing the bargaining power of both parties to any such agreements.

9 E.g., Ares v. Venner, supra, n. 5, and the amendments to the Evidence Acts of the Dominion, Ontario and Saskatchewan, supra, n. 5.

10 E.g., the ability to have one's opponent medically examined under an order of the court: see Ontario Judicature Act, R.S.O. 1960, c. 197, s. 75, as amended by S.O. 1966, c. 73; Alberta Rules of Court 217; General Rules and Orders of the Federal Court of Canada 460. 
it will not be counsel, who for purposes of settlement themselves assume the role of informal decision-maker, but rather a judge or jury who must find the facts. Consequently, to hold back any relevant facts is to deny the fact finder some measure of ability to discover "the truth". It is to mitigate against any weakening of these "powerful statements on both sides of the question" that the courts assess whether relevant evidence and likely sources of it ought to be excluded and whether at the outset the proposed evidential fact has any probative value in respect of the material propositions to be established. Linking these two ideas together, full disclosure and the search through relevancy for the truth, one may ask whether the advocate who fails fully to disclose, because he is performing the very essential role of putting the best gloss possible on his own case and the worst on that of his opponent, is entitled to carry the "fight" theory this far with impunity; or whether he not only has the higher obligation to the court to present every witness and every scrap of evidence to which he may have access but will also suffer an evidential penalty for showing himself loath to perform this duty?

\section{DISCLOSURE AND SUBORNATION}

Legislation may occasionally grant severe enough sanctions to induce the participants in civil litigation or a criminal prosecution to refrain from suppressing evidence or lying to the court. The most stringent of these are to be found in the Criminal Code which, under the general heading of "Misleading Justice," imposes very stringent penalties upon persons found guilty of perjury, ${ }^{11}$ of giving contradictory ${ }^{12}$ or fabricated evidence ${ }^{13}$ with the intent to mislead, or of perverting or obstructing the "course of justice". ${ }^{14}$ Much less punitive and damning are the consequences following upon the failure of a party to adhere to the procedures for the discovery and inspection of documents relating to matters in issue. Under the Criminal Code" an accused "is entitled" to inspect certain documents after his committal or at his trial. However this has been interpreted ${ }^{16}$ to give the judge hearing the application for inspection either before or even at the trial itself a discretion as to whether he will or will not grant the order.

On the civil side, there are the penalty provisions of rules of practice and procedure which attempt to induce the parties to accept a complete and exhaustive discovery of documents. For example, the litigant or solicitor who is derelict in disclosing any document may find himself either denied the right to use it later in evidence, subject to civil contempt or attachment proceedings, or with his claim or defence struck out. ${ }^{17}$ Again, the person who refuses lawfully to attend an ex-

\footnotetext{
" Canadian Criminal Code, 88. 120-121, R.S.C. 1970, c. E-34.

12 Canadian Criminal Code, s. 124.

$13 \mathrm{Id} .8 .125$.

14 Id. 8. 127.

is Id. 8. 531.

16 R. v. Torrens (1962) 40 W.W.R. 75 (Sask.) (D.C.); R. v. McNeil (1960) 31 W.W.R. 232 (Sask. Mag. Ct.) See also R. v. Lantos (1963) 45 W.W.R. 273 (B.C.C.A.); Martin, Preparation for Trial, [1969] Special Lectures of the Law Society of Upper Canada 221 at 235.236; Problems in Ethics and Advocacy, [1969] Special Lectures of the Law Society of Upper Canada 279 at 320-322; Bowen-Colhurst, Some Observations on the Duties of a Prosecutor, (1969) 11 Crim. L.Q. 377 at 381-382; Grosman, The Role of the Prosecutor. (1968) 11 Can. B.J. 580; Norton, Discovery in the Criminal Process, (1970) 61 J. of Crim. L. Criminology and Police Sci. 11.

17 Eg., Alberta Rules of Court 195 and 197; Ontario Rules of Practice 352; Federal Court Rules 460.
} 
amination for discovery or become a witness, who refuses to be properly sworn or affirmed, or who refuses to answer proper questions also subjects himself to the civil counterpart of contempt proceedings. ${ }^{18}$ It is true that, at the discovery stage and subsequently at the trial itself privilege may be claimed in respect of documents and other communications received by a lawyer for purposes of his brief. A most important illustration of this is to be found in the reports which experts will be asked to furnish. This of course can lead to "expert shopping" to which the rules of procedure and evidence respond by placing limitations on the number of experts that any party may call on a particular issue ${ }^{19}$ and affording the court the assistance of lay assessors. ${ }^{20}$ Because of the predominance of personal injury actions and the invaluable need for the opinions and testimony of medical witnesses on such occasions, these rules have been specially modified to account for the presence of this particular expert. In order to apply the principle of full disclosure to this area, Ontario ${ }^{21}$ first attempted to require "all medical reports" to be made available to adverse parties. When this was struck down ${ }^{22}$ as being a non-procedural rule and hence beyond the powers of the Rules Committee, the Legislature added an amendment to the Evidence Act ${ }^{23}$ which, subject to leave being granted by the trial judge, prohibited ${ }^{24}$ a medical practitioner from being a witness unless copies of his medical report, expressly made admissible under the amendment, ${ }^{25}$ had been given to all other parties to the action. Here too it is apparent how a truly pure adversary theory has been made to give way to fuller disclosure to an opponent of some of the bases for one's case. And yet, the mechanism for accomplishing this purpose has produced a solution which might exclude entirely from the court the contents of the document in question and the evidence which the doctor might otherwise be able to give. ${ }^{26}$ It is true that an opponent, if he can gain access to this same information, may

\footnotetext{
1n Cf. Alberta Rules of Court 703, Federal Court Rules 2500 and Canadian Criminal Code, s8. 472, $632-636$.

19 E.g., Alberta Evidence Act, R.S.A. 1970, c. 127, 8. 11; Canada Evidence Act, R.S.C. 1952, c. 307, s. 7.

20 E.g., Alberta Rules of Court 218; Ontario Rules of Practice 267.

21 Ontario Rules of Practice 352a; revoked by Ont. Reg. 242/67 (1967), s. 17.

22 Circosta v. Lilly [1967] 1 O.R. 398 (C.A.).

${ }^{23}$ R.S.O. 1960 , c. 125 , as amended by S.O. 1966 , c. 51 , and S.O. 1968 , c. 36. See also similar amendment to the Saskatchewan Evidence Act. S.S. 1969, c. 51. Compare this provision with rules of procedure (e.g., Alberta Rules of Court 217 and General Rules and Orders of the Federal Court of Canada 467) that authorize the court to order the injured party to be examined by a doctor, at the expense of the party requesting the order, and that require this party to deliver a copy of the medical report to the person being examined. Here too, one penalty that may ensue from a refusal to deliver a copy of the report is the exclusion of this doctor's testimony at trial. It is interesting to speculate whether this aspect of the rules, which purports to make such a doctor an incompetent witness and not merely exclude from the trial only those matters that depend for their existence on the rules, would be held ultra vires or not. There exists that fine line which divides the practice and procedure of the court from substantive matters such as the rules of evidence. So, it has been held beyond the powers of rules of procedure to attempt to alter the evidential privilege attaching to documents (Circosta v. Lilly, supra, n. 22, In Re Grosvenor Hotel (No. 2)[1965] 1 Ch. 1210, per Lord Denning M.R.. Even where a procedural rule authorized court to order a medical examination, the medical report in the hands of the party obtaining the order remained subject to the privilege clothing it under the law of evidence (Milburn v. Phillips (1963) 44 W.W.K. 637 and Jaworski v. Wilkinson (1966) 58 W.W.R. 211). Of course, the rule creating the medical report could subject it to conditions and presumably, as is the situation in the case of evidence obtained upon an examination for discovery, deal with its admissibility at trial. But that must be kept distinct from the medical report based on an examination in no way dependent on the rules. How can they interfere with the laws of evidence that govern the admissibility of such a report and the competence of the examining doctor to testify? (cf. Alberta Rules of Court 217(7)(b) and 217(8), and Schanz v. Richards (1970) 72 W.W.R. 401).

24 S.O. 1968 , c. 36, s. $50 \mathrm{a}(3)$.

2s Id. s. $50 \mathrm{a}(1)$.

26 Id. s. $50 \mathrm{a}(3)$. See also Alberta Rules of Court 217 and comment on 217, supra, $n$. 23. A comparison of Alberta's Rule 195, the Federal Court's Rule 494 and Ontario's Rule 352 leads once more to the question
} of ultra vires rules of practice discussed supra, $n .23$. 
himself be able to bring it before the court, but such good fortune may well depend on costly investigation or happenstance and not on the effects of these evidential and procedural rules. If the facts contained in the document or medical report gravely impair or prejudice the case of the party who possesses it, there could hardly be much incentive for disclosing them to the other side. Consequently, not only will the court be denied access to what might very well be highly probative evidence but its ignorance of this suppression will not even permit any adverse inferences to be drawn against the reticent party.

A pure "fight theory", one that had implicit within it the power and right of any party to put only his best face forward, has still to be subject to some Queensberry rules. The party who interviews and follows the recognized practice ${ }^{27}$ of "coaching" his witness merely subjects himself and this witness to the rigours of an adversary system and its most formidable weapon, the right of cross-examination. On the other hand, he may transgress these ethical bounds by inducing a witness, through fear ${ }^{28}$ or the offer of reward, ${ }^{29}$ to give false testimony on his behalf. This may, of course, destroy his credibility. However, such evidence may also offend some exclusionary rule and thereby create a difficult dilemma for the courts. For example, in Lizotte v. The King, threats uttered by the accused to a witness that "I have killed one already, I am able to kill another" were characterized as being both an attempt to suborn a witness and as character evidence. The conflict between the statement's admissibility in respect of the former purpose and its prejudicial effect on jurors who might be led to give too much weight to what they saw as the evil character of the accused was resolved in favour of the latter. The trial judge ought to have exercised his discretion against the admissibility of this evidence.

If, however, the form which the inducement takes does not smack of character evidence or some other quality which would lead to its being subject to one of the exclusionary rules, the court cannot ignore the fact that in allowing to be introduced this threat or offer of reward it will have difficulty confining the purpose and effect of the evidence to discrediting the witness. Does such evidence have any other purpose? Does the attempt at suborning a witness indicate anything about the veracity of the party's own case, or does it merely illustrate an over-reaction by him to the usual anxieties of participants about the eventual outcome of the litigation or prosecution? Doubtless his conduct has interfered with a fundamental assumption of both the "fight theory" and "truth theory" of litigation: that witnesses are possessed of a genuine willingness to tell the truth. This might be overcome by instructing the finder of fact to ignore the evidence offered by the witness, as much as this may result in the elimination as well of truthful and cogent testimony. The courts, however, have chosen to advance beyond this more negative position and attribute positive

\footnotetext{
2: E.g., remarks made by members of panel discussions reproduced as Problems in Litigation, (1953) 31 Can. B. Rev. 503 at 512.514; Problems in Ethics and Advocacy, [1969] Special Lectures of the Law Society of Upper Canada 279 at $320-324$.

in Lizotte v. The King [1951] S.C.R. 115.

29 R. v. Watt (1905) 20 Cox C.C. 852; Moriarty v. London, Chatham \& Dover Ry. Co. (1870) L.R. 5 Q.B. 314.
} 
consequences to the party who, unable to stifle these normal anxieties and confine himself to interviewing and "coaching" his witness, is prompted to offer him inducements. Such conduct is evidence from which an inference can be drawn that the party "thought he had a bad case;"30 that "he disbelieves in his own case". ${ }^{31}$ From this conclusion it is then a short step to characterizing this party's conduct as an admission by him "not necessarily that he thought his case untrue, but that it was not a good one."32

\section{DISSIPATION OF PRIVILEGE}

This link between the law of evidence and the consequences of criminal conduct has also led to the disabling of the protective privilege granted to communications between a solicitor and his client. When a privilege has been dissipated and evidence which would not otherwise reach the trier of fact is ordered admitted into the proceedings, the actual result of trying to conceal facts or practise a fraud upon the courts is rather to add to the facts available, thereby increasing the likelihood that the truth will out. In $R$. v. Cox, ${ }^{33}$ the defendants were charged with conspiracy to defraud a third person who had obtained judgment against one of the defendants and who, when he tried to execute against the judgment, was met with a bill of sale of the partnership assets of the judgment debtor to the other defendant. The Crown was faced with trying to prove the sale was not bona fide and that the partnership had been dissolved after judgment and not, as endorsed on the deed of partnership, beforehand. The Crown wished to rely on a conversation concerning the partnership, which took place between the defendants and their solicitor after the judgment but before the date of inscription. The defendants claimed this conversation was privileged. So it would have been, and a vital fact excluded, but for the preliminary finding that this communication with their solicitor "was a step preparatory to commission of a criminal offence" and "for the purpose of being guided or helped in committing it." 34

This case underscores the presence of two very fundamental cleavages. The first required the court, before addressing itself to the ultimate issue of guilt or innocence of the defendants, to ask whether the communications in question arose out of attempts to commit the very crime for which they were now being tried. It may be thought that, particularly in non-jury trials, the court should still be able to exercise independent judgment in respect of the ultimate issue. And certainly this conclusion is borne out by the recent majority opinion of the Supreme Court ${ }^{35}$ which permits the accused on a voir dire to be asked whether his confession is true and by the decision ${ }^{36}$ that a magistrate who allowed a change of plea only after he had heard the Crown read its version of the facts was not tainted by bias and could himself try

\footnotetext{
3v Moriarty v. London, Chatham \& Dover Ry. Co., supra, n. 29 at 319.

II $R$. v. Watt, supra, n. 29 at 853.

32 Supra, 'n. 30 at 320 . See generally, Maguire and Vincent, Admissions Implied from Spoliation or Related Conduct, (1935) 45 Yale L. J. 226.

ss R. v. Cox (1884) 15 Cox C.C. 611 (C.C.R.). See also R. v. Colvin ex p. Merrick [1970] 3 O.R. 612 at 617 (H.C.).

st $R$. v. Cox, supra, n. 33 at 612.

is De Clercq v. The Queen [1968] S.C.R. 902.

.66 Chudy v. The Queen [1971] 1. W.W.R. 80 (B.C.S.C.).
} 
the charge. But perhaps more important still is the recognition ${ }^{37}$ that to proceed otherwise would be to acknowledge that the privilege could never be removed, a consequence that in its apotheosis of the adversary system and execration of the solicitor's role as an officer of the court could hardly be countenanced and yet which has been recognized by imposing on the party seeking to remove the privilege the burden of establishing a prima facie case that the substance of the communication was in furtherance of some definite unlawful act. ${ }^{38}$

The second, and more fundamental, cleavage is revealed in the ethical decision the solicitor or barrister may have to make. On the one head is his duty to the court, an obligation that finds its roots in the idealistic image of this tribunal as a source of truth, the fountainhead of justice. On the other hand, he is obligated to do his very best for his client, to do battle on his behalf. The tension between these two obligations ${ }^{39}$ is perhaps best observed in those situations where the offence has already been committed and counsel is then consulted or retained. Though Mr. Justice Stephen was careful to disclaim that "whether the advice was taken before or after the offence will always be decisive as to the admissibility of such evidence," 40 at this later point in time when the criminal process will have actually begun to move against those suspected of the crime the protective cloak of defence counsel becomes even more important. However, the privilege in question acquires no greater strength. Where in murder cases a lawyer advises his client to "get rid of the weapon and sit tight" 41 or tells the wife of the accused to wash the blood off the clothes immediately, ${ }^{42}$ such communications have been found "calculated to further or conceal a criminal act" 43 and not clothed with any privilege. The adversary theory must give way to a search for truth, but why this quickening passion for the latter should here have led to a precipitous decline of one traditional rule of the game is the evident fear that drastic measures are necessary to preserve the very game itself. It might be a rather interesting inquiry that sought to determine the principal motivation behind these procedural and evidential reforms: was it further to enhance the court's ability to discover the true facts, or did this become the rationalization for essential modifications needed to retain the very acceptability of this familiar method of fact-finding.

But at the trial itself a party may not have gone so far as to have tried to suborn a witness and hence actively pervert the course of justice. Relying on the adversary system and its evidential concomitant, the doctrine of burden of proof, he may simply refuse to assist his opponent by disclosing to him sources of evidence potentially beneficent to the latter's own case. Such conduct can hardly be

s7 Bullivant v. Att. Gen. for Victoria [1901] A.C. 196 (P.C.).

s* Bullivant v. Att. Gen. for Victoria, supra, n. 37; Re U.S.A. v. Mammoth Oit Co. (1925) 56 O.L.R. 635 per Hodgings J.A. (dissenting on another point); Fremont Canning Co. Ltd. v. Wall [1940] $0 . W . N .62$ (Master); Re Goodman and Carr and M.N.R. [1968] 2 O.R. 814 (H.C.); Butler v. Board of Trade [1970] 3 W.LR. 822 (Ch.D.).

39 Dubin, Preliminary Problems, [1969] Special Lectures of the Law Society of Upper Canada 1 at 3-12; Problems in Ethics and Advocacy, [1969] Special Lectures of the Law Society of Upper Canada 279 at 279-313; Problems in Litigation, supra, n. 27 at 508-520.

iv $K$. v. Cox, supra, n. 33 at 621 .

"Clark v. The State (1953) 261 S.W. 2d 339 (Texas).

12 Gosselin v. The King (1903) 33 S.C.R. 255.

is Id. at 277. 
characterized as an admission that the non-disclosing party has little or no faith in his own case, nor can the solution just observed, where a solicitor-client privilege is claimed, be applied to have disclosed a communication which is already before the court. Here, subject to discovery, interrogatories and the inspection of documents, non-disclosure of the weaknesses of one's case is inherent in the present system. Yet the law has restrained itself from giving free rein to what might seem to follow naturally from such a premise.

\section{NON DISCLOSURE, SUPPRESSION AND DESTRUCTION OF EVIDENCE}

\section{Real or Documentary Evidence}

Highly relevant documentary or real evidence may not have been introduced at trial. Moreover, it may turn out that one of the parties has destroyed or actively suppressed this evidence after litigation was contemplated. ${ }^{44}$ On the one hand, the courts have sometimes taken drastic action against such a person: by ordering his opponent to hold and enjoy the estate in question until "the defendants should produce the deeds, and the Court thereupon take further consideration and order;" 45 by committing him to the Fleet until he should produce them; ${ }^{46}$ or by ordering the lands in question to be assigned to trustees upon trusts highly unfavourable to this person. ${ }^{47}$ However, such drastic measures for ferreting out the truth may be attempting the impossible. If the documents have in fact been destroyed, an order will not resurrect them, no matter how severely punitive against the alleged offender. Thus, Mr. Rumsley, while in the Fleet, swore that the articles in issue had been destroyed and asked for his release; the Court replied that he would not be discharged "until he had consented to admit the articles were to the effect in the bill." 48 But, apart from the question of whether a document has been either actively spoliated or inadvertently lost, it may often be going to great lengths to conclude "that the contents of the thing spoliated are what they have been alleged to be." 49 How then is the court to thwart the efforts of the alleged spoliator, continue to preserve the advocate's power to decide how he might most cogently present his case and avoid the rigours of the best evidence rule? This last hurdle has been met by introducing one more exception in favour of secondary evidence of the document, ${ }^{50}$ but unless the court were willing to proceed further and perhaps construe it against the guilty party, it may be that this situation would then cease to be distinguishable from the one where the document was accidently lost or destroyed, whether post or ante litem motam.

And so it is at this point that the courts impose their penalty on the secretive litigant. In Armory v. Delamirie, ${ }^{51}$ where the finder of

\footnotetext{
"4 2 Wigmore on Evidence 8. 291 (3rd ed.).

is The King v. Arundel (1617) Hob. 109.

"Sanson v. Rumsley (1706) 2 Vern 561.

17 Dalston v. Coatsworth (1721) P. Wms. 731.

4s Sanson v. Rumsley, supra, n. 46.

19 Barker v. Ray (1826) 2 Russ. 63 at 73.

so Young v. Holmes (1718) 1 Stra. 70; Anon. (1698) 1 Ld. Raym. 731; Sanson v. Rumsley, supra, n. 46, at 561n. s1 (1722) 1 Stra. 505.
} 
a brooch on defendant's property gave it into the custody of the latter's apprentice for a valuation, only to discover later that the stones had been removed by the defendant, the plaintiff in a trover action led evidence to establish the value of the finest stones that would fit the brooch. Chief Justice Pratt directed the jury that unless the defendant produced the object in dispute and showed that it had a lower value "they should presume the strongest against him and make the value of the best jewels the measure of their damages."52 Similarly, where documentary evidence is being held back by a party the court may, as we have already seen, bring to bear the punitive means that are a precursor of such modern ones as civil contempt, attachment and striking out the pleadings of the recalcitrant person, or may, as in Armory v. Delamirie, raise an inference against him. Though the language of the courts, particularly in older cases, sometimes leads to doubt whether the inference merely follows from the introduction of this item of circumstantial evidence or is a true legal presumption, ${ }^{53}$ it may be necessary to distinguish amongst the situations in issue. ${ }^{54}$ For example, because the party accused of converting jewelry ${ }^{55}$ or turkeys $^{56}$ refuses to produce the property, the court cannot accurately assess damages and cannot force production save by linking these two into a principle: the defendant will be liable on the basis of the jewelery's highest value and the turkeys being of Grade A quality. Necessity has given birth to this "presumption", rebuttable nonetheless by a defendant willing to bring the material object before the court and prove otherwise. ${ }^{57}$ However, there is less willingness to assume that documentary evidence concealed by one of the parties necessarily contains the substance claimed for it by his opponent.58 Moreover, although secondary evidence of its contents will provide a surer source of truth than the bare allegations to be found in a party's pleading, it may be that the party introducing this secondary evidence will damage his own cause when it is discovered that he possessed the original as well. 59

Ultimately, there may be two chasms that must be bridged by the trier of fact. The first is opened in the face of little or no secondary evidence coming to his assistance. The second will accompany the introduction of this evidence when it leaves the construction of the document doubtful and unclear. But even these two are preceded by other questions: did the party conceal or destroy this documentary evidence and, if so, why did he do so? One therefore finds the following synthesia: ${ }^{60}$

52 Id.

s3 Cf. Roe d. Haldane v. Harvey (1769) 4 Bu. 2484; Clunnes v. Pezzey (1807) 1 Camp. 8; Gray v. Haig (1855) 20 Beav. 219; Att. Gen. v. Halliday (1867) 26 U.C.Q.B. 397 at 411-414; Betts v. Venning (1873) 14 N.B.R. 267 (C.A.); Ockley v. Masson (1881) 6 O.A.R. 108; St. Louis v. The Queen (1895) 25 S.C.R. 649.

st Supra, n. 44 at $182 \cdot 183$.

ss Armory v, Delamirie, supra, n. 51.

so Green v. Brampton Poultry Co. Ltd. (1958) 13 D.L.R. (2d) 279 (Ont. H.C.). See also Clunnes v. Pezzey, supra, n. 53.

57 It is true that the best evidence rule does not apply strictly to real evidence, but secondary evidence here would still seem to suffer from the same disabilities that led Willes J., where documentary evidence was in issue, to state: "Parol evidence could not be given by the party who had the deed in his power. and refused to produce it; though it might be the adverse party." (Roe $d$. Haldane v. Harvey, supro, n. 53, at 2489).

so Barker v. Ray, supra, n. 49.

50 See Taylor v. Durno (1919) 53 N.S.R. 199 per Ritchie E. J. (C.A.).

so Hale v. Leighton (1903) 36 N.B.R. 256 at 257 (C.A.). See also Att. Gen. v. Halliday, supra, n. 53; Betts v. Venner, supra, n. 53. 
...[I]f the party has in his power documentary evidence that he states would strengthen his case, and withholds it purposely, the jury may draw reasonable inference as to why he did it, and what, if the book was shown, it would or might show.

Even were he to have expressed no opinion on whether the book would or would not assist his case, the courts still regard this failure as bringing "a great slur upon his cause," 61 as evidence "always to be taken most strongly against" him. ${ }^{62}$ Crucial to this reasoning, of course, is the act of a despoiler. The strength of the inference will be measured against a party's purposefulness in failing to disclose. ${ }^{63}$ On the other hand, if the documentary or real evidence has been lost or destroyed through sheer accident or before any dispute had arisen, the construction of an inference, let alone a presumption, would founder. In one case, therefore, before concluding on the note of presuming "everything most unfavourable to [the despoiler], which is consistent with the rest of the facts, which are either admitted or proved,"64 Sir Samuel Romilly M. R. closely examined the facts to discover whether the destruction of the documentary evidence would support this inference. In another, ${ }^{65}$ though from Quebec and hence concerned only with the Civil Law, the Supreme Court found that the trial judge had erred in believing that any such inference or presumption remained irrebuttable. These civil suits must be contrasted with the position of the accused in the criminal arena where he "is never forced to produce any evidence; though he should hold it in his hands, in Court." 66 Therefore, it was erroneous of a trial judge to charge the jury that an adverse inference could be drawn against an accused who had failed to introduce highly material evidence into the proceedings; there was no obligation on him to do so. ${ }^{67}$

\section{Testimonial Evidence}

Testimonial evidence that is withheld presents greater difficulty still. A court may be perplexed by the significance to be given an item of real evidence or the words and symbols in a document, but at least the object to be interpreted does, or did at one time, exist, and its absence may in the circumstances just discussed be readily remedied through the introduction of secondary evidence. But the objects of interpretation in the case of testimonial evidence are the words of the witness himself. If he does not enter the box, in the absence of admissible out-of-court statements by him, the court is left with the ostensibly unfathomable mind of this non-witness, a situation perhaps not unlike that to be observed where no secondary evidence of the real or documentary evidence is available and nothing has been adduced to show that the thing or document in issue ever existed at all. But, whereas this latter kind of evidence will be left to speak for itself, a witness can be cross-examined.

\footnotetext{
ot Ward v. Apprice (1705) 6 Mod. 264 at 264. See also Roe d. Haldane v. Harvey, supre, n. 53. But cf. Cooper v. Gibbons (1813) 3 Camp. 363.

62 Att. Gen. v. Dean and Canons of Windsor (1858) 24 Beav. 679 at 706.

63 Att. Gen. v. Halliday, supra, n. 53.

64 Gray v. Haig, supra, n. 53 at 226.

63 St. Louis v. The Queen, supra, n. 53.

66 Roe d. Haldane v. Harvey, supra, n. 53 at 2489

67 R. v. Beauchesne [1933] 4 D.L.R. 138 (Sask. C.A.). Cf. Att. Gen. v. Halliday, supra, n. 53.
} 
The party presenting himself or another as a witness thereby incurs an additional risk, one that may lead him to draw back from having enter the box a person whose evidence is not essential to his case and who, on the contrary, may actually weaken it. Therefore, we are again confronted with the need for resolving the two clashing fundamental principles in operation here: should a party be asked to serve the cause of his opponent; on the other hand, will the court be able to function properly and acceptably if it is denied relevant facts to which the parties have access?

First and foremost there is the party who fails to make himself a witness to his own cause. Where it is the plaintiff, upon whom lies the ultimate burden of proof, who has not testified, courts have been willing to place in the scales some sort of negative inference in favour of the defendant. This refusal to testify will militate against his case, or, as Dixon J. once said, will call "for close scrutiny of the facts upon which he relies and as confirmatory of any inferences which may be drawn against him." 68 Clearly, such an inference will only have a marked influence on the result when the evidence adduced by both parties leaves the court in somewhat of a quandry as to whether or not the plaintiff has satisfied his onus of proof. So, where the plaintiff claimed alimony on the basis of her husband's desertion, her refusal to give evidence, in the absence of any evidence that he lived apart from her against her will or without sufficient cause, simply underscored the plaintiff's failure to prove her case. ${ }^{69}$

The purposefully reticent defendant is liable to suffer the same fate for failing to support his own case, either during the present trial or when he refused to appear in earlier proceedings to which he was party and which are intimately linked to those now in issue. ${ }^{70}$ Although it has been baldly stated that the defendant who despite his knowledge of the matters in issue fails to give evidence shall have raised against him "the presumption ... that the facts (upon which he relies) do not exist,"71 this language would seem too strong; rather, "a party not denying a fact which it is in his power to deny, gives a colour to the other evidence against him"72 and leads to triers of fact reasonably being able to draw "their own conclusions". ${ }^{73}$ This "colour" refers to the weight to be given to plaintiff's own case. For example, the issue in a trover action was how much lumber belonging to the plaintiff the defendant had actually received, a fact which the plaintiff knew little about and yet upon which he had the burden of proof. The New Brunswick Court of Appeal found no misdirection to the jury that: ${ }^{74}$

... if the case was left doubtful on the part of the plaintiff, the defendant, who must have known how much of this wood was taken from Lepreau by his orders,

\footnotetext{
ansurance Commissioner v. Joyce (1948) 77 C.L.R. 39 at 61 per Dixon J. See also the language of Rich J. at 49.

68 Batt v. Batt (1916) 27 D.L.R. 718 (Alta. S.C.).

70 Taylor v. Willans (1831) 2 B. \& Ad. 845; Simpson v. Robinson (1848) 12 Q.B. 511; Mash v. Darley [1914] 3 K.B. 1226 (C.A.).

"Shanklin Executor v. Smith (1932) 5 M.P.R. 204 at 238 (N.B.C.A.). See also Barker v. Furlong [1891] $2 \mathrm{Ch} .172$ at 184.

72 Boyle v. Wiseman (1895) 10 Exch. 647 at 651 per Alderson B. arguendo.

73 Id. at 641 per Parke B. arguendo.

7 Tufts v. Hathaway (1858) 9 N.B.R. 62 at 63-64 (C.A.). See also Hammersmith and City Ry. Co. v. Brand (1869) 38 L.J.Q.B. 265 per Lord Cairns (dissenting on another point) (H.L.); Black v. Tunq [1953] V.L.R. 629 (C.A.).
} 
and the value and quantity of what came into his possession, and who might have been a witness and have stated all these particulars, had not been brought forward as a witness, which would naturally lead to the inference that his testimony would not have helped his case.... It is an inference so naturally arising to a jury themselves possessing ordinary sense and acumen, that such a remark might be hardly necessary.

Similarly, where only the defendants had knowledge of some of the breaches of contract that had occurred, their failure to testify, even though not bound to do so, gave them no reason "to complain if they have left the jury to draw inferences where they could have supplied facts." 75 The jury was entitled to find that more than one breach had occurred.

Easily discernible here are the very positive benefits which may fall to the plaintiff when this allegedly negative inference is raised against his silent antagonist. The former must make out at least a prima facie case to avoid being non-suited and beyond this must convince the jury or other trier of fact of the merits of his case on a balance of probabilities. If, as the Court of Appeal suggested, the plaintiff's case remained doubtful at the end, this inference might yet play so strong a role on his behalf as to permit the jury to transform this doubt against his case into a probability of its truth. Thus the colour or weight which this inference will possess can vary in intensity from case to case. So, plaintiff's doubtful proof of facts essential to his case does not prevent the trial judge from holding "that very slight evidence pointing to their existence may be treated as sufficient to justify a jury in holding that they do exist, if, but only if, there is no explanation of that evidence by the defendant."76 The same reasoning applies to a non-jury trial. ${ }^{77}$ Where a strong circumstantial case has been made out against a defendant's wrongful taking of the deceased's jewellery, his refusal to answer the charge adds to the suspicions of his honesty and makes easier the court's task of finding that all the objects claimed by the executors did fall into the hands of the defendant. ${ }^{78}$ The colour given to plaintiff's case may in reality be the vital one of whose evidence is to be believed. Where a defendant refused to give evidence and relied entirely on the advantageous portions of his examination for discovery, the court simply gave far less weight to this evidence than it bestowed upon plaintiff's testimony because by his actions the defendant had refused to have himself and his evidence subjected to the searching scrutiny of crossexamination. ${ }^{79}$

In all these situations the inference raised by defendant's silence had some, if only a tittle of, evidence adduced in plaintiff's favour upon which to act. However it may be that with respect to a particular material fact to be established no evidence at all has been led. It has been held that with the burden of proof lying upon the plaintiff this gap in his case could not be bridged by

\footnotetext{
is St. John River SS Co. v. Star Lines SS Co. (1911) 40 N.B.R. 405 at 411 (C.A.). See also Miller v. McCuaig (1899) 13 Man. R. 220 (Q.B.); Mason v. Grandel (1951) 3 W.W.R. 536 at 542, aff'd. on other grounds [1953] I S.C.R. 459 (Sask. C.A.).

is De Givia v. Darling Island Stevedoring \& Lighterage Co. Ltd. (1941) 42 S.R. (N.S.W.) 1 at 4 (C.A.).

"Mudrazia v. Holjevac [1970] 1 O.R. 275 at 277 (H.C.).

7א Koyal Trust Co. v. Diamant [1953] 3 D.L.R. 102 (B.C.S.C.).

${ }^{74}$ Young v. Ford (1952) 5 W.W.K. 652 (B.C.S.C.). See also Miller v. McCuaig, supra, n. 75.
} 
exclusive reliance on his mute opponent. ${ }^{80}$ The reference earlier to plaintiff's establishment of a prima facie case leads one to ask whether the decision on this question by the court can be assisted by this negative inference. The question is plagued by procedural niceties not the least of which is the right of the defendant to ask for a nonsuit or judgment at the end of the plaintiff's case and the effect upon this right should he then elect to call evidence. ${ }^{81}$ If the court decides the issue of non-suit when defendant makes his motion at the end of the plaintiff's case, the difficulty of finding any inferences on the basis of defendant's failure to testify is apparent. If that decision is reserved, then the court can rely on the evidence of both parties, including any negative inferences arising from defendant's failure to respond to or explain plaintiff's case against him. ${ }^{82}$

Here again the court seeks a via media. In paying its respects to both prevailing doctrines it continues to pursue a relative version of the truth and simultaneously refuses to overthrow one very fundamental rule of the trial game that depends so largely on the predominant roles assumed by the advocates. Certainly, a pristine perspective of the trial process might focus largely on the goal of victory and hardly find it credible that one party should, without the expectation of some ultimate advantage in the struggle, offer himself or his cause as a point-blank target to his opponent. But unless bloody and turbulent private feuds which government at one time sought to eclipse were to be brought nakedly into the courtroom as into a colosseum, each party had to be reassured by court procedures that his contention could be as fully elucidated as he thought necessary and would be fairly considered by the arbiter, that he would have some reasonable opportunity for destroying the case of his opponent and that a decision which possessed the stuff of acceptability and enforceability would be readily forthcoming. And so the history of civil procedure narrates a tale of the evolution of oral pleadings to written ones, of the controlled expansion of forms of action, of the increasing complexity, and finally petrification, of process and procedure. But throughout, including both the nineteenth century era of reform, of what, in part, has been so graphically and terrifyingly described in Dickens' Bleak House, and the less radical changes of our own day, there is to be discerned not so much the triumph of truth over the adversary method as the reformulation of the latter to reflect amendments to the rules of the game which themselves place greater emphasis on the exposure of a greater potential array of facts for the benefit of court and parties alike.

It does not follow that because the forms of action have lost their pre-eminence, and examination for discovery, interrogatories and the discovery and inspection of documents are likely to add to the evidential facts brought before the court, as well as prevent surprise and help counter the efforts of an uncommunicative party, the advocate's role and the adversary system have been denigrated. Rather, in much the same way that new football or hockey rules force the

so Gibb v. Ellis (1959) 17 D.L.R. (2d) 262 (B.C.S.C.); Mudrazia v. Holjevac, supra, n. 77; McQueen v. Great Western Ry. Co. (1875) L.R. 10 Q.B. j69.

" For a recent discussion of the law in this area and reference to authority, see M.V. "Polar Star" v. Louis Denker Inc. (1966) 53 1).L.R. (2d) 181 (P.E.I.S.C.).

.2 De Gioia v. Darling Island Stevedoring \& Lighterage Co. Ltd., supra, n. 76 at 3-4, 11-12. 
participants in these sports to amend their tactics, so here too a party to litigation and his counsel will be led to alter their perspective and the means they must use to win their case. It is for counsel to assess as accurately as he is able the evidence so far introduced into court and the substance and credibility of the testimony his own client is likely to give. Perhaps he has presented a strong enough case that the negative inference, however highly coloured, will be unlikely to breach it successfully. Perhaps the risk of a party in the witness box destroying his own case is more to be feared than any inference, a fear which one feels motivated counsel in some of the cases just discussed to shield his client from cross-examination. But it will not be difficult for the court, aware of the basic issues of fact and the evidence already introduced, to estimate that this silent party must have something of relevance to tell and that he either should be induced to do so or have this failure weigh against him. On the other hand, it might be argued that his opponent as well can call him to testify ${ }^{83}$ and if the opponent fails to do so an inference might similarly be raised against his case. But this is to ignore the weapon of cross-examination and the limits placed on characterizing such a party witness as a hostile witness. Moreover, the plaintiff is placed at somewhat of a disadvantage if it is a defendant who refuses to become a witness. The plaintiff may not become aware of this reluctance until the defendant has concluded his case by which time it is too late either to gain the benefits of cross-examination or to call him as his own witness.84 Here the law is favouring the "fight" theory over the search for the truth. And so a balance or tension between the two is maintained.

\section{FAILURE TO PRODUCE KNOWLEDGEABLE WITNESSES}

A somewhat similar result flows from the failure of a party to produce as a witness someone who might be expected to enlighten the court on any of the matters at hand. It is true that the ordinary witness differs from a party to the proceedings inasmuch as the latter having an interest in the proceedings was at common law incapable of being a witness. Statute has removed this fetter. ${ }^{85}$ However, the rules of procedure now subject the party to an action to discovery. In permitting the contents of this examination to be used at trial by his opponent, 86 the law has still placed the party witness in a somewhat less enviable position than the ordinary witness. On the other hand, it is more expected of a party that he will be present during the course of the trial of his action. Not only is there less reason for questioning the absence of a person not immediately involved in the suit, but since there is no property in a witness why should one party be allowed to damn the other for not bringing forth to testify a person whom he may as easily subpeona himself ? That perhaps is why the inference is more easily drawn against a party when he and the witness in question have such a close or special relationship that

${ }_{83}$ E.g. Alberta Rules of Court 292 and Ontario Rules of Practice 274. See Harwood v. Wilkinson (1929) 64 O.L.R. 658 at 663 and 667 , off'd. [1931] S.C.R. 141.

*4 Barker v. Furlong, supra, n. 71.

ss E.g., Canada Evidence Act, R.S.C. 1970, c. E-10, 8. 3; Alberta Evidence Act, R.S.A. 1970, c. 127, 8. 4; and Ontario Evidence Act, R.S.O. 1960, c. 125, s. 5.

ws E.g., Alberta Rules of Court 214, Ontario Rules of Practice 329 and Federal Court Rules 494(9). 
the court is able to find that it was he that had by far the greater responsibility to call the witness to give evidence. Such a witness might be the employee of one of the parties, 87 the partner of the company being sued, 88 the agent of a party, ${ }^{89}$ the spouse of one of the parties, ${ }^{90}$ or his sibling. ${ }^{91}$

Still, this formal relationship seems by itself a weak foundation on which to construct an inference that depends so greatly on the power of one party to produce the only person or a very important person, who could give evidence on the matter in issue. In a dissenting judgment Mr. Justice Locke refers to the onus of proof on a party making it incumbent on him to adduce "whatever evidence was available and under his control."92 There is no reason for believing that this "control" exists necessarily between spouses, siblings or the employer and his no longer employed servant. Must something, therefore, be superadded? For example, the court's ability to make this adverse inference is strengthened if the defendant refers to the responsibility of an employee in his own testimony ${ }^{93}$ or calling only one of the employees present at the time of the accident, ${ }^{94}$ then fails to bring forth those whom it is acknowledged have relevant evidence to offer. A like result follows from the failure to testify of a husband who has acted as advisor and representative of his wife, ${ }^{95}$ or the older brothers of a defendant required to establish adverse possession, whose residence in and knowledge of the area were such that they "could have given evidence of the extent of the clearing made by the father better than the defendant himself could give."96 But apart from the assistance obtained from events of the past there is the influence of the present predicament in which at trial the defendant now finds himself. His employee has been involved in an accident, the plaintiff has made out his prima facie case and the defendant has failed to call to testify a person in his employ who was a witness to, if not a participant in, the very act claimed to be negligent. The employer here, as in the situations where he fails to call the employee who it is established has personal knowledge of another's scope of authority, ${ }^{97}$ expertise $^{98}$ or theft, ${ }^{99}$ is confronted with the almost inexorable forces of common sense and experience which dictate that plaintiff's evidence not only establishes a prima facie case but points an accusing finger at someone under the defendant's control. Not to produce this person is almost tantamount

s: Jones v. Great Western Ky Co., (1930) 144 L.T. 194 (H.L.); Royal Trust Co. v. Toronto Transportation Comm. [1935] S.C.R. 671; Winnipeg Electric Rwy. Co. v. Schwartz (1913) 49 S.C.R. 80; Barnes v. Union SS Ltd. (1954) 13 W.W.R. 72 (B.C.S.C.) rev'd. ultimately on other grounds by Supreme Court of Canada (1956) 5 D.L.R. (2d) 535; Baumann v. Springer Construction Ltd. (1967) 58 W.W.R. 592 (Alta. S.C.); Murray v. Saskatoon [1952] 2 D.L.R. 499 (Sask. C.A.); Kullberg's Furniture Ltd. v. Flin Flon Hotel Co. Ltd. (1959) 16 D.L.R. (2d) 270 (Man. C.A.); R. v. Arnold [1971] S.C.R. 209 per Spence J. (dissenting on another point) (S.C.C.); Moore v. R. Fox \& Sons [1956] I All E.R. 182 (C.A.); Vaughton v. London \& N.W. Ry Co. (1874) 12 Cox C.C. 580; Boyce v. Chapman (1835) 2 Bing. N.C. 222.

wynch \& Co. v. U.S. Fidelity \& Guaranty Co. [1971] 1 O.R. 28 (H.C.).

by Blatch v. Archer (1774) 1 Cowp. 63.

so Kabatoff v. Popoff [1939] 3 D.L.R. 807 (Sask. K.B.); Naruzny v. Stoddart (1957) 21 W.W.R. 118 (Man. Q.B.).

"B Brigss v. McBride (1878) 17 N.B.R. 663 (C.A.).

92 Tyson v. Waldie [1954] 2 D.L.R. 401 at 410 (S.C.C.).

${ }^{93}$ Moore v. R. Fox \& Sons, supra, n. 87.

94 Barnes v. Union SS Led. supra, n. 87.

95 Kabatoff v. Popoff, supra, n. 90; Naruzny v. Stoddart, supra, n. 90.

96 Briggs v. McBride, supra, n. 91 at 666.

97 Baumann v. Springer Construction Ltd., supra, n. 87.

9* Moore v. R. Fox \& Sons, supra, n. 87.

yy Vaughton v. London \& N.W. Ry. Co., supra, n. 87; Boyce v. Chapman, supra, n. 87. 
to an admission that this person's evidence could only wreak further injury upon the defendant's own case.

It may be wondered how formal the relationship between the reluctant party and his non-appearing witness must be. On the one hand, there is the very recent decision of the Appellate Division of the Alberta Supreme Court which refused to make any inference or presumption against the plaintiffs who had failed to call as a witness a person who was neither a party nor their employee. ${ }^{100}$ Again, the person accused of alienating the affections of plaintiff's wife who still lived at home had no reason to summon her as his witness. ${ }^{101}$ On the other hand, there may have existed between them some form of tie, however casual, that would lead a court to surmise that that party is far more likely than any other to have relied on that witness' testimony. For example, courts have so held where there had been evidence that the persons not called had been "associated with the prosecutor in the evil practices" alleged ${ }^{102}$ and where the person in question had both been present when the owner of the automobile allegedly refused to consent to its use by the driver and also had a close personal relationship with her. ${ }^{103}$ The courts have even permitted the inference to be made when at the date of the trial the witness in question was no longer in the defendant's employ ${ }^{104}$ and, consequently, when to speak of that party's "control" over the evidence might seem somewhat specious save insofar as plaintiff may be under the greater disability of identifying and locating this witness. Then too, it is appropriate to recall that, generally, this witness' absence will merely help to confirm an opponent's evidence. Therefore, if it is the defendant who has been neglectful and who has the task of meeting plaintiff's evidence, the failure of the party with the secondary burden of proof here, and $a$ fortiori if it be the ultimate burden, to produce someone who once worked for him and who then had sufficient intimacy with the transaction in issue to be thought able to throw some light upon it is likely to loom large in the mind of the fact finder.

But all this assumes a great deal. Why should either party despair that the evidence he has chosen to adduce will not satisfy the various burdens of proof lying on him? Why should he be forced by an allegedly impartial arbiter to produce the witness, or the real or documentary evidence for that matter, that he does not exclusively control and yet feels will only assist his opponent's cause? This obverse side of the coin is expressed by Mr. Justice Haines ${ }^{105}$ who, in a negligence action against an automobile dealer who allegedly had failed to use sufficient care in the repair of the brakes of plaintiff's automobile, had before him the incriminating written report and out-ofcourt statements made by the then chief service advisor of the dealer. The defendant never called his former employee, though he was present in court. Haines J. referred to the care which the court must

\footnotetext{
Iwi McLean v. American National Fire Insurance Company' [1971] I W.W.R. 598.

${ }_{101}$ Marangos v. Harold (19:29) 52 O.L.R. 395 (C.A.).

11'- R. ex rel. Lambri v. Labuuchere (1880) 14 Cox. C.C. 419 at 432.

11.. Moreau v. Devost (1970) 2 N.B.R. (2d) 539; 17 D.L.R. (3d) 415 (C.A.).

i'. Diederichs v. Metropolitan Stores Led. (1956) 20 W.W.R. 246 (Sask. Q.B.); Traders Finance Corp. Led. v. Nurray Distributing (1967) 60 W.W.R. 129 (Man. Q.B.).

11.: Phillips v. Furd Motor Co. of Canada Led. [1970] 2 O.R. 714 (H.C.); rev'd on other grounds, supra, n. 7 .
} 
take "in drawing inferences as to the non-production of a witness."106 The factors he considered were the availability of this witness to either side, the party upon whom lies the onus of proof and, finally, the tactical considerations inherent in the adversary system:107

In these circumstances, I would think that the plaintiffs would much prefer to subject Grover, the chief service adviser, to a searching cross-examination rather than to encounter the disability of examining him in chief. And, in the circumstances, I can readily understand why the defence would prefer not to call him.

The underlying basis for this result may be usefully contrasted with the words of Grimmer J., who, though having before him the case of a silent defendant, expressed somewhat different sentiments: ${ }^{108}$

She would ordinarily, under the circumstances, if everything was honest and aboveboard, have been a useful and natural witness, for it is only when the truth is ascertained that the law can properly be applied in the just settlement of disputes.

It may turn out that the inference serves no real purpose at all. If it be drawn against a defendant who already has thrust upon him the onus of producing some evidence that he was not negligent, either as an inference from the facts ${ }^{109}$ or as the result of the application of res ipsa loquitur, ${ }^{110}$ and he brings forward none, then the adverse inference here can merely reinforce and confirm the assessment that the plaintiff has established his case. Then too, this inference does not necessarily depend for its creation on the failure of a party or his witness to enter the witness box. In more dramatic fashion the witness may, when called, run out of the courtroom. ${ }^{111}$ Less forceful but nonetheless emphatic was the situation of the defendant who had evidence taken on commission from witnesses in the United States and who then asked the commissioner not to return it to Canada. ${ }^{12}$ Somewhat akin to this was a plaintiff's reaction to the attempt by the defendant to introduce a will in order to help confirm the testimony of one of the latter's witnesses and the conversation he had had with the testator. The plaintiff objected and the will was withdrawn. The jury were held to have been properly instructed that they could draw from the objector's conduct "that it was not worth his while to have the will put in, because it would not support his case."113

Then again, the witness who has not appeared may be a medical one. Though just another form of expert or opinion evidence, and hence subject to the abuse of what was earlier described as "expert shopping", medical evidence has presented such unusual difficulties that special provisions may be found in various Judicature Acts and Rules of

\footnotetext{
106 Id. at 730 .

jut Id. See also Harwood v. Wilkinson, supra, n. 83 at 663 where Ridell J. stated that counsel: ... and not the Court was the sole and only judge as to what witnesses to call.... Counsel, not the Judge, is to determine what witnesses he is to call in support of his case; and while the Judge has the right to comment upon and base his judgement pro tanto on the non-production of any witness or witnesses, he has no right to criticise the discretion observed by counsel in so deciding-there may be a score of things that the counsel knows which the Judge cannot know that determine his decision, and he, not the Judge, is dominus litis.

un Shanklin Executor v. Smith, supra, n. 71 at 238.

109 Murray v. Saskatoon, supra, n. 87.

10 Kullberg's Furniture Ltd. v. Flin Flon Hotel Co. Ltd., supra, n. 87.

11 Blatch v. Archer, supra, n. 89.

112 Hesse v. St. John Ruy. Co. (1900) 30 S.C.R. 218.

11. Sutton v. Devonport (1857) 27 L.J.C.P. 54.
} 
Court.114 Within the context of our own discussion, the failure of the plaintiff to present to the court the doctor who examined him is bound to leave the impression that the doctor was not called because his evidence would not assist the claimant's case. ${ }^{115}$ But a party may consult many doctors and choose to call only the benign ones. Having no access to the plaintiff's body and being subject to the doctor's professional obligation to keep his confidences, a defendant might easily be denied the power to consult and retain his own medical experts in the matter. Such an unfortunate consequence, one that would make a mockery of both the adversary system and the court's purported search for the truth, has led to amendments to the rules of practice permitting the defendant to have his own doctor examine the plaintiff. It has also encouraged courts, which discover a plaintiff's exercise in selectivity, to rule that he "ought to call all doctors who attended him in respect of the matters that are in dispute or explain why he does not do so."116. Otherwise an adverse inference will be drawn against him. Similarly, the defendant who has had his doctors examine the plaintiff and who then does not produce the results of these examinations will have these same derogatory inferences drawn against his case. ${ }^{117}$ One case did refuse to draw any such inference, except where the testimony of a medical witness expressly referred to his disagreement with the diagnosis of the doctor whom plaintiff did not call, because the latter having been subpoenaed by the defendant would if his testimony had differed from his colleague have been called by this party. ${ }^{118}$ Such a conclusion may here have been true in fact but as a general proposition it patently ignores realities. A doctor's professional obligation prevents him from disclosing confidences save when the judicial process compels him to do so and even then "it is too much to ask defendants to gamble... by calling (him) blindly."119

But circumstances may deny the applicability of this adverse inference. Already noticed is the situation in which the trial judge places an apparently greater than usual emphasis on the "fight" theory of justice. This predisposition characterizes the failure to produce an important witness not as an attempt to conceal evidence injurious to his case but rather as a legitimate tactic to disclose voluntarily nothing of benefit to one's opponent. This reasoning, of course, is founded on efforts to second-guess the motives of counsel and undercuts the whole rationale of the inference under discussion.120 In refusing to draw the inference other courts, however, have been far less sweeping and have addressed themselves to the question of whether these particular circumstances allow the inference to be made. So, for example, where the person in likely possession of relevant evidence and not called neither is nor ever has been an employee of one of the parties,

\footnotetext{
"W E.g. Ontario Judicature Act, R.S.O. 1960, c. 197. 8. 75 as amended; Ontario Evidence Act, R.S.O. 1960, c. 125, 8. 50a; Saskatchewan Evidence Act, R.S. 1965, c. 80, 8. 30B; Alberta Rules of Court 217; Federal Court Rules 460.

11 Dowsett v. Dowsett [1942] O.W.N. 593 (C.A.); Magel v. Krempler (1970) 75 W.W.R. 37 (Man. C.A.).

"16 Barker v. McQuahe (1964) 49 W.W.R. 685 at 689 (B.C.C.A.) See also Levesque v. Comeau (1970) 16 D.L.R. (3d.) 425 at 432 (S.C.C.); Kaytor v. Lion's Driving Range Ltd. (1962) 40 W.W.R. 173 (B.C.S.C.).

"Albus v. Ryder [1956] Vict. L.R. 56 (S.C.).

11 Kaytor v. Lion's Driving Range Lid., supra, n. 116.

119 Barker v. McQuahe, supra, n. 116 at 689.

iw See Phillips v. Ford Motor Co. of Canada Ltd., supra, n. 105; Kaytor v. Lion's Driving Range Ltd., supra, n. 116. Cf. Harwood v. Wilkinson, supra, n. 83.
} 
no inference will be drawn against him. ${ }^{121}$ Even where the necessary relationship is found present, however, no adverse effect can be given to the absence of a witness who is unavailable through death, ${ }^{122}$ illness, ${ }^{123}$ inexplicable absence from the jurisdiction, ${ }^{124}$ or some form of legal incompetence or disqualification. ${ }^{125}$ The unavailable person whose credibility the court doubts certainly can afford but a tenuous basis at best for such an inference. ${ }^{126}$ Similarly, there can be no inference drawn from a party's failure to produce legally inadmissible documents during his case, ${ }^{127}$ or from their destruction by him long before there was any dispute between the litigants. ${ }^{128}$ For the very substance of the principle being applied is this: ${ }^{129}$

The nonproduction of evidence that would naturally have been produced by an honest and therefore fearless claimant permits the inference that its tenor is unfavorable to the party's cause.

\section{THE TRUTH CONCEPT AND THE ADVERSARY CONCEPT IN CRIMINAL PROCEEDINGS}

Within the criminal sphere the principal protagonists, the "truth" and "fight" theories, must give way to still other values which are most succinctly, though not necessarily accurately, described by reference to the polarizing battle cries of "law and order" and "civil liberties". It is true that here, as in civil litigation, much of the law of evidence seems designed to enhance the court's opportunities for reaching the truth. What better illustrates this than the rules which grant the judge discretion to exclude many kinds of relevant evidence that are more prejudicial than probative, which demand corroboration in many situations and which envelop statements made by the accused to a person in authority with a protective shield? However, such modern legislation as the Canadian Bill of Rights, ${ }^{130}$ the Bail Reform Bill ${ }^{131}$ and the Young Offenders Bill, ${ }^{132}$ and the continuing debate upon the controls to be exercised over wiretapping by the police are directed only in part to the truth-finding process. Other values, impossible to ignore when the State finds itself pitted against the individual subject, are here in play, and from time to time one observes the legislature in the throes of searching out a balance. On a more continuous and measured basis the courts too have had to resolve procedural problems possessed of the same normative components. Where the judges have looked beyond the bare analysis of precedents and statutes into the philosophical and social consequences of what they were doing, the conflict among, and hence vital importance of,

\footnotetext{
131 McLean v. American National Fire Insurance Company, supra, n. 100.

1 .2t National Trust Co. Ltd. v. Wong Aviation Ltd. [1969] S.C.R. 481.

12. R. v. Arnold, supra, n. 87.

124 See Diederichs v. Metropolitan Stores Lid., supra, n. 104. Of course, evidence may be taken from such persons on commission: sec Levesque v. Comeau, supra, n. 116.

12.s Supra, n. 44 8s. 286.288.

120 Morcau v. Devost, supra, n. 103.

137 K. v. Beauchesne, supra, n. 67.

Ias Gray v. Haig, supra, n. 53 at 226.

1: Supra, n. 44 at 162. Wigmore's emphasis. See generally, Note, Evidence: Failure to Call Available Witnesses, (1949) 34 Cornell L.Q. 637.

150 S.C. 1960 , c. 44.

1.J 19 Eliz. II, c. 37.

1 s.2 19 Eliz. II, Bill C-192.
} 
these norms has become only too visible. For example, the rule requiring the Crown to prove that a confession was given voluntarily may be described as directed only at insuring against the introduction of untrue evidence, and yet recently we find statements that this control was devised for the further purpose of protecting the individual against self-incrimination. ${ }^{133}$ This principle of simple fairness to an accused is itself so bound up with the fundamental underpinning that rests our society on the integrity of the method and system of law enforcement that one case has apparently held that refusal to allow a person access to counsel contrary to the Canadian Bill of Rights will, apart from the criterion of voluntariness, destroy the admissibility of his confession. ${ }^{134}$ Moreover, the confrontation of these competing values is made that much more vivid in the series of cases that have recently discussed the admissibility of illegally seized evidence. ${ }^{135}$

It is against such a general background that, within the criminal trial process, the adversary system must function. Moreover, unlike the position of counsel in a civil trial, the law here supplements the other protections bestowed upon an accused in the form of a personal fetter placed upon the efforts of the prosecutor: ${ }^{136}$

The position of the Crown Attorney is not that of ordinary counsel in a civil case:
he is acting in a quasi-judicial capacity or as a minister of justice and ought to
regard himself as part of the Court rather than as an advocate. He is not to stuggle
for a conviction nor be betrayed by feelings of professional rivalry to regard the
question at issue as one of professional superiority and a contest of skill and pre-
eminence.

But the author of this, himself a Crown Attorney, dispelled any notion that this suggested the complete demise of the adversary system of justice: "vigour is frequently demanded to see that the court is not misled-that the course of justice is not warped."137 So, for example, it is not proper for a prosecutor to express his personal opinion to the jury on the guilt of the accused, ${ }^{138}$ to play upon their passions by raising fears about the consequences of acquitting him, ${ }^{139}$ or to refer to matters upon which no evidence has been led ${ }^{140}$ or which come only from his own personal experience. ${ }^{141}$ Such inflammatory tactics also apply to civil proceedings, but not only do the effects of the appeal provisions under the Criminal Code ${ }^{142}$ and the enactments that regulate civil litigation ${ }^{143}$ place a heavier burden on the appellant in a civil appeal than on the person appealing a conviction, but as has been seen the obligation lying upon Crown counsel is the more onerous one of regarding "themselves rather as ministers of justice assisting

is De Clercq v. The Queen [1968] S.C.R. 902 per Cartwright J. and (in dissent), Hall, Spence and Pigeon JJ.; Commissioners of Customs and Excise v. Harz [1967] 1 A.C. 760 at 820.

i3 $R$. v. Ballegeer (1968) I D.L.R. (3d) 74 (Man. C.A.). Cf. O'Connor v. The Queen [1966] S.C.R. 619; R. v. Martel (1968) 64 W.W.R. 152 (Alta. D.C.) R. v. Emele (1940) 74 C.C.C. 76 at 81 (Sask. C.A.).

iss $R$. v. Wray [1971] S.C.R. 272; King v. The Queen [1969] 1 A.C. 304 (P.C.); R. v. Sadler [1970] 1 W.L.R. 416 (C.A.), petition for leave to appeal to House of Lords dismissed [1970] 1 W.L.R. 426.

136 Bull, The Career Prosecutor of Canada, (1962) $53 \mathrm{~J}$. of Crim. L. Criminology and Pol. Sci. 89 at 95. See also Grosman, The Prosecutor, at 84-86 (1969); R. v. Chamandy [1934] O.R. 208 at 211 (C.A.).

1:12 Bull, supra, n. 136 at 96.

ist Boucher v. The Queen (1955) S.C.R. 16.

139 R. v. Vallieres (1969) 9 C.R.N.S. 24 (Que. C.A.).

1su $R$. v. Turvey (1970) 9 C.R.N.S. 212 (N.S.C.A.). Or, perhaps, to conceal evidence substantiating the defence of insanity from the court: $R$. v. Frank [1971] O.R. 693 (H.C.).

11 Pisani v. The Queen (1970) 15 D.L.R. (3d) 1 (S.C.C.).

142 S. 592. See Colpitts v. The Queen [1965] S.C.R. 739.

is E.g., Ontario Judicature Act, R.S.O. 1960, c. 197, s. 28; Alberta Rules of Court 519. 
in its administration than as advocates."144 Again, therefore, the law has not so much emasculated the adversary process as it has amended the rules of the game by which it is to be played; the muting of this piece of weaponry demonstrates how other values than truth are sought to be enhanced and encouraged. Truth, together with perhaps the even more deep-seated desire to preserve the present system, may lie behind the "Misleading Justice" provisions of the Criminal Code referred to earlier. But, the far more limited provision for the discovery of documents from the Crown in criminal proceedings, however generous the prosecution in practice and always at its own sufferance may be, ${ }^{145}$ and the necessity for "discovery" from the accused having to be in the form of strict compliance with the search-andseizure provisions of both the Code and the common law, bespeak the presence here of something more than a search for truth.

\section{ADVERSE INFERENCES IN CRIMINAL PROCEEDINGS}

\section{Accused's Right Not to Testify}

Insofar as the adverse inference that may be drawn against a party who fails to present himself as a witness is concerned, in criminal proceedings the only such "party" who is likely to qualify will be the accused. And yet in contrast with civil procedure, the law here goes out of its way to make the accused an incompetent and non-compellable witness for his antagonist, the Crown. As if to emphasize the continuing burden of proof that generally lies throughout on the Crown, ${ }^{146}$ the right of the accused to remain silent and rely on the Crown's failure to satisfy its heavier onus of proof, and the different context of the criminal process discussed briefly above, not only were two distinct series of statutes originally considered necessary in order to remove the original taint of incompetence from parties in proceedings, ${ }^{147}$ but the obvious adversarial tactic and judicial function of remarking to the jury upon this silence of the accused was removed from both prosecutor and trial judge. ${ }^{148}$ Although the debate about whether the law should continue to act so generously to the accused and at the same time place fetters upon the court's ability to get at the truth rages still, ${ }^{149}$ the shelter given an accused by this provision of the Evidence Act seems only too penetrable. As the majority in a recent Supreme Court decision pointed out: 150

... it would be 'most naive' to ignore the fact that when an accused fails to testify after some evidence of guilt has been tendered against him by the Crown, there must

is Boucher v. The Queen, supra, n. 138 at 26.

145 Humphreys, The Duties and Responsibilities of Prosecuting Counsel, [1955] Crim. L Rev, 739 at 741.742 Devlin, The Criminal Prosecution in England, at 93-96. See also the literature referred to supra, n. 16.

ito Woolmington v. D.P.P. [1935] A.C. 462.

157 Evidence Act 1851 , c. 99 (civil); Criminal Evidence Act 1898, c. 36 (criminal).

15. Canada Evidence Act, R.S.C. 1970, c.E.10, 8. 4(5). It is to be noted that 8. 4 of the Act not only sets out the special rules governing the competence and compellability of the accused and his or her spouse but by ss. 5 emphasizes an intention to treat the accused differently from ordinary litigants. Also to be noted is the apparent judicial limitation placed upon this provision in favour of jury trials only; $R$. $v$ Binder [1948] O.R. 607; Pratte v. The Queen [1965] 1 C.C.C. 77 (Que. C.A.); R. v. Bouchard (1969) 2 N.B.R. (2d) 138 at $156-157$ (C.A.).

${ }^{149}$ See, e.g., Haines, The Right to Remain Silent, (1970) 4 Law Society Gazette 78; Jaffary, The Right to Remain Silent: A Reply, (1970) 4 Law Society Gazette 150; McWilliams, In Defence of Silence, (1970) 4 Law Society Gazette 229, Maloney, The Accused's Right to Remain Silent, The Globe and Mail, May 13 1970, at 7 and May 14, 1970, at 7; Cross, The Right to Silence and the Presumption of Innocence (1970), 11 J.S.P.T.L. 66; Zield, Right to Silence: A Rejoinder to Professor Cross (1970), 11 J.S.P.T.L. 76.

1.t. McConnell and Beer v. The Queen [1968] S.C.R. 802 at 809. 
be at least some jurors who say to themselves 'If he didn't do it, why didn't he say so'. It is for this reason that it seems to me to be of the greatest importance that a trial judge should remain unhampered in his right to point out to the jury, when the occasion arises to do so in order to protect the rights of the accused, that there is no onus on the accused to prove his innocence by going into the witness box.

This would appear to justify comment made "for the protection of accused persons against the danger of having their right not to testify presented to the jury in such fashion as to suggest that their silence is being used as a cloak for their guilt."151 It may indeed extend to remarks upon the subject by the Crown prosecutor acting in his "quasi-judicial capacity or as a minister of justice."152 It is with some irony that one perceives that with an apparent disregard for the function of the accused's own counsel to decide how to conduct the defence and, more specifically, whether or not to refer to this right, the Supreme Court has turned the "fight" theory or adversary system of justice on its head.

Nevertheless, this decision does reiterate that inference which, on the basis of the "ordinary sense and acumen"153 of the trier of fact, be he judge or jury and be the proceedings civil or ciminal, will be drawn from a party's failure to answer the allegations made against him by others in the course of their evidence. The silence of the accused cannot forbid them "to use their intelligence and to consider the absence of denial or explanation"154 or "do otherwise than to adopt the conclusion to which the proof tends." 155 However, as in civil litigation, this omission on the part of an accused cannot supply a defect in the Crown's own proof and hence is an inference that can only influence the weight of the evidence already before the court. ${ }^{156}$ But, as has just been noted, this inference has a particularly maleficent effect upon the accused in criminal proceedings. In civil litigation one very important purpose in drawing adverse inferences against the silent party is to encourage him to testify and, in spite of the power in his opponent to have him enter the box, to penalize him for not volunteering evidence that would help explain that which the court has heard. But the laws of criminal procedure and evidence purport to protect the defendant from becoming a witness. To apply this same inference as readily here seems tantamount to removing with one hand what has been bestowed by the other. What is perhaps more disturbing is how indirectly the blow to this declared right of the accused is accomplished. To conclude that silence adds cogency to the accusations which he has not denied speaks only in the language of intuition, based as relevancy in the law of evidence is on human experience. Such a result not only turns a blind eye to the accused's express rights but fails to acknowledge any similarity between this inference and the more forceful implied admissions that may arise in respect of extra-curial statements made by others in the presence of the defendant. It is true

\footnotetext{
18s Id.

132 Bull, supra, n. 136 at 95.

15s Tufts v. Hathaway, supra, n. 74 at 63 .

1st $R$. v. Steinberg [1931] O.R. 222 at 236, aff'd [1931] S.C.R. 421.

iss $R$. v. Welch (1931) 57 C.C.C. 202 at 206 (N.S.C.A.) See also R. v. Jacquard (1950) 98 C.C.C. 72 (N.S.C.A.); R. v. MacLeod [1968] 2 C.C.C. 365 (P.E.I.C.A.).

136 $R$. v. Nykolyn (1947) 90 C.C.C. 72 (Man. C.A.); R. v. Comba (1938) 70 C.C.C. 205 (Ont. C.A.), aff'd [1938] S.C.R. 396; R. v. Jacquard, supra, n. 155.
} 
that the latter is productive of a positive evidential fact, the statement which by his silence in the circumstances he acknowledges to be true, rather than a mere negative inference, and that it deals with an adverse statement made out of court rather than with testimony given under oath in the present proceedings. Nevertheless, the court in both situations has addressed its mind to the likely truthfulness of the statement's content. And yet in one the context in which it was spoken and not denied, including the accused's right to remain silent in the face of accusations before peace officers, is closely examined on this question, whereas in the other such circumstances are ignored to the extent that the acknowledged right of an accused to say nothing seems hardly to bear at all upon the question. ${ }^{157}$

Perhaps some cogent relationship between his silence and the veracity of the accusations does exist, but whether his rights and this truthseeking role of the court are being properly safeguarded at present and whether, in the absence of following the suggestion of reformers in this field, ${ }^{158}$ this unobservable and ineluctable negative inference can only have its consequences for an accused softened in the manner approved by the Supreme Court, are nice questions indeed. An accused may remain out of the box for reasons other than a desire to suppress the truth; for example, his personality may be such that, innocent or not, he fears disproportionate devastation from crossexamination; he may not wish to fall afoul of the provisions permitting his past criminal record to be produced in court; 159 or he may simply wish to rest on his lawful right to have the prosecution prove every material fact beyond a reasonable doubt. If truth is not necessarily assisted by this negative inference, neither are the other important values. It has already been noted that the attempted compromise worked out by the law has eroded away some of the protection purportedly conferred on the accused and, in so doing, has assisted the Crown prosecutor only in an oblique and tortuous way. As for the "fight" theory of justice, counsel for the defence finds himself not only fettered by the risks attendant upon the operation of this inference, but his freedom to defend against it as he sees fit may be gravely impaired by a trial judge, or perhaps even a prosecutor, who chooses to air the accused's reticence publicly in order to protect his rights.

\section{The Silence of Other Witnesses}

Beyond the accused himself, to ask what inferences will flow from the failure of some other potential witness to enter the box draws one into the difficulty already observed to be present in civil litigation: in the absence of being able to assign a property interest in a witness to any particular party, the court had to build any such in-

157 Interestingly enough, the courts have recognized that at an earlier proceeding to which the accused was not a party a witness' accusation demands no denial on the part of the accused sitting in the courtroom. As McDonald J.A. reasoned: "I can scarcely imagine a spectator in the Police Court rising in the midst of a trial to protest against a statement being made by an accused person or by any one else. It is a well-known rule of evidence that no one shall be taken, from his silence, to admit the truth of a statement made in his presence unless it is made on an occasion when a reply from him might be properly expected." ( $R$. v. Kiewitx [1941] 3 W.W.R. 693 (B.C.C.A.)). How analogous this situation is will depend on whether a qualitative distinction can be drawn between the silence of the accused at his own trial and his failure "to protest" against accusations made at an earlier proceeding where he is a mere spectator. Sec also K. v. Appleby (1821) 3 Stark. 33; Child v. Grace (1852) 2 C. \& P. 193.

is Haines, supra, n. 149; Williams, Proof of Guill, chapter 3 (3 ed.).

1sy Canada Evidence Act, R.S.C. 1970, c. E·10, 8. 12. 
ferences on the greater expectation that one party, rather than some other would call this person to testify. If the Crown seeks to prove its case by evidence that would omit the testimony of a person whose name is mentioned in the course of the trial by other witnesses or whom the defence claims has material information to give the court, his silence throughout may lead the trier to reason in two ways. Either the Crown was afraid to produce a witness who would do injury to its case, or the accused equally thought that too much harm would redound to his defence from this man's appearance in court. There seems no greater reason here than in civil proceedings for being loath to draw such an adverse inference so long as the necessary link between witness and party can be constructed. ${ }^{160}$ But that may not be so easy to establish. For example, where the defence of insanity was raised and neither side called the medical superintendent of the provincial mental hospital, who was admittedly an expert in insanity cases and who remained in the courtroom throughout the proceedings, the defence could not claim beneficial inference in its favour. ${ }^{161}$ Vital here was the burden of proof that lay on the accused and the impropriety of the Crown to lead evidence in respect of this issue. On the other hand, unlike the special status accorded the accused, the silent witness may form the object of comment by counsel ${ }^{162}$ or the court, ${ }^{163}$ who may ask the trier of fact to apply his experience and common sense to the situation.

To speak of an adverse inference generally is to suggest that both the accused and the Crown, like civil litigants, have equal status, rights and immunities during the course of the trial. But that hardly is in harmony with some of what has just been discussed. Instead one is induced to ask what obligation the Crown has to call every available witness to testify. In fact the Crown has no such duty and may refuse to have enter the witness box a person alleged by the defendant to have knowledge which would assist both his case and, of course, the court. Here one observes the "truth" and "fight" theories vying more directly with one another. The prosecutor will wish to accomplish the task of proving his case beyond a reasonable doubt, a task that cannot help but produce the tension referred to earlier between his duty "as a minister of justice" and his role as an advocate. In the balance are the advocate's discretion to prove his case as he sees fit and the Crown's quasi-judicial duty not to conceal from the court a witness who may be able to shed light on the matters in dispute. ${ }^{164}$ Awareness of his existence will permit the defence to call him, but whether the prosecutor must have him on hand in the courtroom or only furnish the defence with his name and whereabouts remains debatable. ${ }^{165}$ However, subject to a discretion resting on the trial judge to ensure that the accused is given a fair opportunity to defend himself against the charge, the Crown still has full discretion to decide if it will call a particular witness and, consequently, whether

\footnotetext{
two E.g. K. ex rel. Lambri v. Labouchere, supra, n. 102; Lizotte v. The King, supra, n. 28; $R$. v. Watt, supra, n. 29.

161 K. v. Kierstead (1918) 30 C.C.C. 175 (N.B.C.A.) Cf. R. v. Frank, supra, n. 140.

in. K. v. Shelly (1927) 49 C.C.C. 179 (Ont. C.A.).

16. K. v. Palmer [1970] 3 C.C.C. 403 (B.C.C.A.).

164 Dallison v. Caffery [1964] 2 All E.R. 610 at 618 and 622. See generally, A Fresh Look at the Suppressed Evidence Rule, (1968) 34 Brooklyn L. Rev. 269.

in: Cf. R. v. Capelli (1907) 10 O.W.R. 637 (C.A.); R. v. McClain (1915) 7 W.W.R. 1134 (Alta. C.A.); R. v. Woodhead (1847) 2 Car. \& K. 520; $R$. v. Gordon (1842) 12 L.J.M.C. 84; R. v. Dickson (1946) 31 C.A.R. 146; R. v. Oliva (1965) 49 C.A.R. 298.
} 
the defence will have an opportunity to apply the rigours of crossexamination to him. ${ }^{166}$ Though not reversible error this failure of the Crown to produce a witness for cross-examination by the accused has at times been looked upon with some disfavour by the courts, ${ }^{167}$ but this tells nothing of when courts will actually transform a prosecutor's discretion into a duty. Conscious concealment of an important witness from the accused is one thing, ${ }^{168}$ but will something less wilful do? One formula states: ${ }^{169}$

Witnesses essential to the unfolding of the narrative on which the prosecution is based must, of course, be called by the prosecution, whether in the result the effect of their testimony is for or against the case for the prosecution.

This might be interpreted as requiring the prosecutor only to produce those witnesses who could establish each of the material facts necessary to prove his case. If another witness happened to be available, the accused could not then rely on this construction to force the Crown to call him no matter how credible he might be. ${ }^{170}$ Only if he were "essential to the unfolding of the narrative" 171 would the prosecution have to call him. Otherwise it remains for the prosecution to determine who are the material witnesses.

But is an "essential" witness the same as a "material" witness ?172 If more than one person was present at the time and place of the act for which accused has been charged, is the Crown free to refuse to call one of these because it has already fulfilled its obligation of producing "witnesses essential to the unfolding of the narrative", or will the court compel him to call this "material witness"? Older English cases, ${ }^{173}$ particularly before $R$. v. Woodhead, ${ }^{174}$ no doubt influenced by the procedural impediments then placed in the way of the accused, favoured the latter course. One still finds modern judicial references $^{175}$ to the general practice of prosecutors tendering such witnesses for cross-examination and to their duty to exercise this discretion in such a way as "to further the interests of justice, and at the same time be fair to the defence."176 But in Canada the removal of these impediments, the disclosure of the identity of the witnesses to the defence by the Crown, the power of the defence to call and examine them, and finally the power of the trial judge to interfere and himself order them to appear, may make it far less necessary now to encourage these incursions upon the Crown's discretion.

${ }_{160}$ See Adell Muhammed El Dabbah v. A.G. of Palestine [1944] A.C. 156 (P.C.); Lemay v. The King [1952] I S.C.R. 232; $R$ v. Taylor (1970) 75 W.W.R. 45 (Man. C.A.); $R$. v. Palmer, supra, n. 163; $R$. v. Haase (1964) 50 W.W.R. 321 (B.C.C.A.), aff'd (1964) 50 W.W.R. 386 (S.C.C.); $R$. v. Sing [1936] 1 D.L.R. 36 (B.C.S.C.); $R$. v. MacKinnon [1930] 3 W.W.R. 548 (Alta. S.C.); R. v. Skelly, supra, n. 162; R. v. Hagel (1914) 6 W.W.R. 164 (Man. Q.B.).

187 E.g. Adell Muhammed El. Dabbah v. A.G. of Palestine, supra, n. 166; R. v. McClain, supra, n. 165; R. v. Taylor, supra, in. 166. See also Problems in Litigation, supra, n. 27 at 509.512; The Duty of the Prosecutor to Disclose Exculpatory Evidence, (1960) 60 Col. L. Rev. 858.

low Ziems v. Prothonotary of the Supreme Court of N.S.W. L957 97 C.L.R. 279 at 292-294 and 306-308; Lemay v. The King, supra, n. 166 at 240.241; Dallison v. Caffery, supra, n. 164 at 618.

by Seneviratne v. The King [1936] W.W.R. 360 at $377 \cdot 378$ (P.C.).

171" $R$. v. Hop Lee $[1941]$ W.W.R. 330 (B.C.C.A.).

17 Lemay v. The King, supra, n. 165 at 238, quoting from Seneviratne v. The King, supra, n. 169 at 378.

172 See Rand J. in Lemay v. The King, supra, n. 166.

17i $R$. v. Holden (1838) 8 C. \& P. 606; R. v. Chapman (1838) 8 C. \& P. 558; R. v. Stroner (1845) 1 C. \& K. 650.

17 Supra, n. 165.

17i E.g.. Adell Muhammed El Dabbah v. A.G. of Palestine, supra, n. 166 at 169; Lemay v. The King, supra, n. 166 at $240 ; R$. v. Taylor, supra, n. 166 at 54; R. v. Oliva, supra, n. 165 at 310.

176 $R$. v. Oliva., supra, n. 165 
It is true that the greater power possessed by the trial judge in criminal proceedings to order a witness to testify reflects a more acute awareness than is to be found in civil litigation of having to get at the truth and balance the "interests of justice" and fairness to the defence, ${ }^{177}$ but this hardly diminishes the importance accorded by law to the adversary process. Criminal procedure in this area may be far less the subject of precise and detailed rules than its civil counterpart, but a practice in favour of the discovery of documents and disclosure of the names of witnesses by the prosecution which possesses the advantages in investigative resources can only take the defence so far. What better illustrates the presence of a vigorous "fight" theory than the initiative required of counsel for the accused who must rely on his own skill and resourcefulness in bringing before the court evidence which the Crown in its discretion has decided is not essential to the proof of its case.

\section{CONCLUSION}

Through a prism composed of the suppression, conscious or unconscious, of relevant evidential facts this paper has tried to delve into some of the underlying principles upon which the trial process rests. It is true that I have tended to dwell on two themes of this counterpoint, searching for truth and maintaining the adversary method of trial. However far removed from the Platonic view of Truth the actual findings of fact in any case may be, the truth-seeking goal remains more unyielding and absolute in its nature than the flexible and protean theme that characterizes the "fight" theory of justice. Rules of procedure and evidence may, in respect of the former, be measured against their ability to get at the truth, but for the most part advocates need respond to them only by a change of tactics, an accommodation that leaves the familiar trial process basically intact.

Nevertheless, to concentrate only on these two is to blind one to the broader perspective of all the themes of the composition. ${ }^{178} \mathrm{Men}$ tion has already been made of the crying need for procedural reform, particularly in the last century. The business of the courts had to be accelerated and made more productive; at the same time, not only had our two principal threads to be left inviolate but the cost of the process had to be kept in check. Increasingly, courts were facing competition, no longer from each other, but from new breeds like the arbitrator and administrative tribunal. The success of this last body illustrates nicely the problems which the courts have had to confront. Not only have vast new areas of jurisdiction been conferred on tribunals but traditional ones too have fallen into the hands of this interloper. Here one need only refer to workmen's compensation schemes, settlement of wage disputes between master and servant ${ }^{179}$ and enforcement

\footnotetext{
${ }^{177}$ Cf.. In re Enoch and Zaretsky, Bock \& Co. [1910] 1 K.B. 327; Connor v. Twp. of Brant (1914) 31 O.L.R. 274 at 283-286 (C.A.); Cochlin v. Massey Harris Co. (1915) 8 W.W.R. 286, per Beck J.A.; R. v. Harris [1927] 2 K.B. 587; $R$. v. Wallwork (1958) 42 C.A.R. 153; $R$. v. Tregear (1967) 51 C.A.R. 280; $R$. v. Evans [1964] V.R. 717; R. v. Mandyrk [1939] 2 W.W.R. 300 (Sask. C.A.).

178 See, E.R., Weinstein, supra, n. 1 at 241-246.

179 E.g., Payment of Wages Act, S.B.C. 1962, c. 45. See Board of Industrial Relations v. Ladner Transfer Ltd. (1969) W.W.R. (B.C.C.A.)
} 
of the terms of collective employment contracts ${ }^{180}$ as examples from the past, and to the continuing disputations about the proper forum for resolving injury claims arising out of automobile and other accidents as areas which one day may also be lost to the courts.

Why the courts have ceased to be a forum for the effective resolution of so many disputes remains, of course, the important question. The emphasis that the court and the tribunal will give to each of the various principles undoubtedly differs, but, except for the adversary system of justice, all do remain present in the procedure of each body. The history of the common law and of constitutional developments in England has given lawyers, and the citizenry at large perhaps, a definite bias in favour of the "fight" theory, but if the true measure of a decision-maker's success, tribunal or court, is his productivity, that is the opportunity he has to find the best version of the truth by means that are neither too expensive nor too time-consuming and remain acceptable to the vast majority of people who must endure the system, then the question becomes subject to resolution through scientific investigation. Not only might courts and tribunals be the objects of such analysis, but equally so might one trace out the evolution of tribunals that have moved from more informal inquisitorial procedures to those that have partaken increasingly of what one discovers in a court of law. Official efforts to find a proper balance in the manner in which administrative bodies carry on their business appear in reports of Royal Commissions ${ }^{181}$ and legislative committees ${ }^{182}$ and in statutes of both a general nature ${ }^{183}$ and particular tribunals. ${ }^{184}$ Nevertheless, what these attempts all have in common is a return to more formal procedures, including the presence of lawyers. Whether or not $\mathrm{Mr}$. Justice Lyell was necessarily correct when he proclaimed that legal representation "arises only in a society which has reached some degree of sophistication in its affairs," 185 one need not necessarily conclude that there follows in the lawyer's wake a "fight" theory of justice.

At the heart of any investigation will be the future of the adversary process itself. Throughout, we have observed that by means of such immediate penalties as striking out a litigant's pleadings and by resort to the adverse inference the law has striven to encourage the silent to speak and the concealed object or document to be produced. Indirect methods are employed and in the end if they prove unsuccessful the search for truth may be severely hampered. Again it must be emphasized that truth alone does not dictate the guidelines, but the questions that nonetheless must be asked are: to what extent does the adversary system, the "fight" theory of justice, muffle the truth? And how essential is it not only to the fact-finding process, be if before a court or a tribunal, but more importantly to the vitality of the society of which all this is but a part?

\footnotetext{
Isu See discussion of this subject in Molot, The Collective Labour Agreement and its Agency of Enforcement, (1967) 5 Alta. L. Rev. 274.

181 E.g., The Royal Commission Inquiry into Civil Rights, Report No. 1 (Ont. 1968).

182 E.g., The Report of the Special Committee on Boards and Tribunals to the Legislative Assembly of Alberta (1965).

18s E.g., Administrative Procedures Act, S.A. 1966, c. 1.

184 E.g., The Legal Profession Act, R.S.A. 1970, c. 203, Part 3; The Medical Profession Act, R.S.A. 1970, c. 230, 8. 39; The Law Society Act, S.O. 1970, c. 19, 8. 33; Anti-Dumping Act R.S.C. 1970 c. A-15, Part III.

18: Pett v. Grayhound Racing Association Led. (No. 2) [1970] I Q.B. 46 at 66.
} 